\title{
Effects of dietary supplementation with Lactobacillus acidophilus on the performance, intestinal physical barrier function, and the expression of NOD-like receptors in weaned piglets
}

\author{
Shiqiong Wang ${ }^{1}$, Haihua Li ${ }^{2}$, Chenhong Du ${ }^{1}$, Qian Liu ${ }^{1}$, Dongji Yang ${ }^{1}$, Longbin Chen ${ }^{3}$, Qi Zhu ${ }^{3}$, \\ Zhixiang Wang ${ }^{\text {Corresp. } 1}$ \\ ${ }^{1}$ College of Animal Science and Veterinary Medicine, Henan Agricultural University, Zhengzhou, China \\ 2 College of Animal Science and Veterinary Medicine, Tianjin Agricultural University, Tianjin, China \\ 3 Tianjin Institute of Animal Husbandry and Veterinary Medicine, Tianjin Academy of Agricultural Sciences, Tianjin, China \\ Corresponding Author: Zhixiang Wang \\ Email address: wzxhau@aliyun.com
}

Lactobacillus supplementation is beneficial to the barrier function of the intestinal physical barrier in piglets. However, the mechanisms underlying this beneficial function remain largely unknown. Here, we investigated the effects of dietary supplementation with Lactobacillus acidophilus on the performance, intestinal physical barrier functioning, and NOD-like receptors (NLRs) expression in weaned piglets. Sixteen weaned piglets were randomly allocated to two groups. The control group received a corn-soybean basal diet, while the treatment group received the same diet adding $0.1 \%$ L. acidophilus, for 14 days. As a result, dietary $L$. acidophilus supplementation was found to increase the average daily gain (ADG) $(P<0.05)$, reduced serum diamine oxidase (DAO) activity $(P<0.05)$, increased the mRNA expression and protein abundance of occludin in the jejunum and ileum $(P<$ $0.01)$, reduced the mRNA levels of NOD1 $(P<0.01)$, receptor interacting serine/threonine kinase 2 (RIPK2) $(P<0.05)$, nuclear factor KB (NF-KB) $(P<0.01)$, NLR family pyrin domain containing 3 (NLRP3) $(P<0.01)$, caspase-1 $(P<0.01)$, interleukin $1 \beta(I L-1 \beta)(P<0.05)$ and IL-18 $(P<0.01)$ in the jejunum tissues of the weaned pigs. The expression of NLRP3 ( $P$ $<0.05)$, caspase-1 $(P<0.01)$, IL-1 $(P<0.05)$ and IL-18 $(P<0.05)$ was also reduced in the ileum tissues of the weaned pigs. These results showed that $L$. acidophilus supplementation improves the growth performance, enhances the intestinal physical barrier function, and inhibits the expression of NOD1 and NLRP3 signaling-pathway-related genes in jejunum and ileum tissues. They also suggest that $L$. acidophilus enhances the intestinal physical barrier functioning by inhibiting IL-1 $\beta$ and IL-18 pro-inflammatory cytokines via the NOD1/NLRP3 signaling pathway in weaned piglets. 
1 Effects of dietary supplementation with Lactobacillus acidophilus on the

2 performance, intestinal physical barrier function, and the expression of NOD-

3

4

5

6

\section{like receptors in weaned piglets}

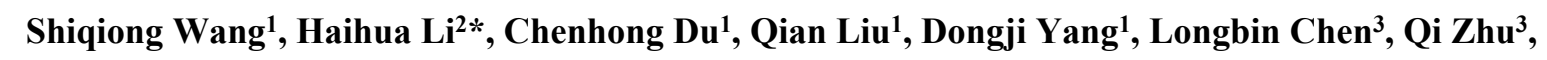

$$
\text { Zhixiang Wang1* }
$$

${ }^{1}$ College of Animal Science and Veterinary Medicine, Henan Agricultural University, Zhengzhou, 450046,

$$
\text { China; }
$$

${ }^{2}$ College of Animal Science and Veterinary Medicine, Tianjin Agricultural University, Tianjin, 300284, China;

${ }^{3}$ Tianjin Institute of Animal Husbandry and Veterinary Medicine, Tianjin Academy of Agricultural Sciences, Tianjin, 300381, China;

*Corresponding author A: Zhixiang Wang

E-mail: wzxhau@aliyun.com

Address: No.15 Longzihu University Area, Zhengdong New District, Henan Agricultural University, Zhengzhou 450046, P.R.China

*Corresponding author B: Haihua Li

E-mail: lihaihuaok@126.com

Address: No.22, JinjingRoad, XiqingDistrict, Tianjin Agncultural University, Tianjin 300384, P.R.China. 


\section{ABSTRACT}

26

Lactobacillus supplementation is beneficial to the barrier function of the intestinal physical barrier in piglets. However, the mechanisms underlying this beneficial function remain largely unknown. Here, we investigated the effects of dietary supplementation with Lactobacillus acidophilus on the performance, intestinal physical barrier functioning, and NOD-like receptors (NLRs) expression in weaned piglets. Sixteen weaned piglets were randomly allocated to two groups. The control group received a corn-soybean basal diet, while the treatment group received the same diet adding $0.1 \%$ L. acidophilus, for 14 days. As a result, dietary L. acidophilus supplementation was found to increase the average daily gain (ADG) $(P<0.05)$, reduced serum diamine oxidase $(\mathrm{DAO})$ activity $(P<0.05)$, increased the mRNA expression and protein abundance of occludin in the jejunum and ileum $(P<0.01)$, reduced the mRNA levels of NOD1 $(P<0.01)$, receptor interacting serine/threonine kinase 2 (RIPK2) $(P<0.05)$, nuclear factor $\kappa \mathrm{B}$ (NF-kB) $(P<0.01)$, NLR family pyrin domain containing 3 (NLRP3) $(P<0.01)$, caspase-1 $(P<$ $0.01)$, interleukin $1 \beta(\mathrm{IL}-1 \beta)(P<0.05)$ and IL-18 $(P<0.01)$ in the jejunum tissues of the weaned pigs. The expression of NLRP3 $(P<0.05)$, caspase-1 $(P<0.01)$, IL-1 $\beta(P<0.05)$ and IL-18 $(P<0.05)$ was also reduced in the ileum tissues of the weaned pigs. These results showed that $L$. acidophilus supplementation improves the growth performance, enhances the intestinal physical barrier function, and inhibits the expression of NOD1 and NLRP3 signaling-pathwayrelated genes in jejunum and ileum tissues. They also suggest that $L$. acidophilus enhances the intestinal physical barrier functioning by inhibiting IL-1 $\beta$ and IL-18 pro-inflammatory cytokines via the NOD1/NLRP3 signaling pathway in weaned piglets. 


\section{INTRODUCTION}

47 As the interface between the external environment and the internal milieu, the physical barrier

function of the intestine is extremely important (Sperandio, Fischer \& Sansonetti, 2015). The integrity of the physical epithelial barrier function depends on the presence of healthy epithelial cells and a normally functioning paracellular pathway. The paracellular pathway is a complex structure predominantly controlled by tight junctions (TJs) between the epithelial cells, which form selective channels that regulate the selective permeability of the intestinal mucosa to endotoxins, bacteria, water, ions, and nutrients (Balda \& Matter, 2016), therefore, the gut has barrier function. Impaired intestinal physical barrier leads to bacterial translocation and increased intestinal permeability (Wang et al., 2014). In mammals, D-lactate originates from the metabolic reactions of intestinal microorganisms because the rapid metabolic enzyme systems that produce D-lactate are absent in them. Therefore, increased serum D-lactic acid concentrations may reflect a dysfunctional intestinal mucosal barrier (Vella \& Farrugia, 1998). DAO, a highly active endoenzyme in the microvilli of the mammalian small intestine, regulates cell proliferation by degrading polyamine, a substance essential for mitosis and meiosis (Peng et al., 2004), and its activity in the blood can be exploited as a useful marker for the integrity of or damage to the intestinal mucosa (Li et al., 2002).

TJs mainly comprise transmembrane proteins such as occludin, claudins, junctional adhesion molecules, zonula occludens (ZO), and other peripheral cytoplasmic proteins (Balda \& Matter, 2016). The occludin protein blocks the gap between cells, forms a TJ structure with the ZO-1 protein, and is expressed in virtually all epithelial and endothelial tissues. Its functions 
67 include the maintenance of cell polarity, and the regulation of signal molecule localization and

68

69

cell permeability (Mariano et al., 2011). TJs act as signaling hubs that direct epithelial proliferation and differentiation (Xie et al., 2016; Volksdorf et al., 2017), the study found that occludin is involved in immune signaling pathways, making it important in cellular physiology (Luo et al., 2017). ZO provides the basis of the structural support for TJs (Rodgers et al., 2013). In addition, the structure and function of TJs depends mainly on the actin cytoskeleton, and these junctions anchor the actin cytoskeleton in the epithelial cells through $\mathrm{ZO}$, with peripheral actin present in the cell connection ring around the top of the cell (Balda \& Matter, 2016). This structure not only provides a barrier function for the epithelial cells, but also changes the membrane permeability via its rapid assembly and disassembly in response to different stimuli (Koch \& Nusrat, 2009). Thus, ZO, which is considered to be a major moderator of TJ permeability (Li et al., 2016), can reversibly modulate intestinal permeability.

Previous studies have shown that disrupting the TJ structure in the mucosal barrier damages the intestinal epithelia monolayer and increases its permeability (Tanaka et al., 2015), and intestinal permeability is exquisitely sensitive to immune cell signaling. As microbial sensors, the NOD-like receptors (NLRs) are thought to recognize and resist microbial pathogens and act to regulate the intestinal flora and intestinal homeostasis. The NLR family contains more than 20 cytosolic receptors in mammals (Wells et al., 2011), and these proteins are involved in complex signaling pathways. NLRs activate the host's defense mechanisms through two major signaling pathways. One detects bacterial peptidoglycan through NOD1 or NOD2 signals, activates NF- $\mathrm{B}$ and MAPK via the serine/threonine kinase RIP2 (RICK/CARDIAK/RIPK2), and causes the 
release of pro-inflammatory cytokines and chemokines, such as tumor necrosis factor $\alpha$ (TNF- $\alpha$ ), IL-12 and IL-8 (Kobayashi et al., 2002). In the other pathway, caspase-1 is activated through several NLR signals, which leads to IL- $1 \beta$ secretion and programmed cell death. Recent studies have shown that NLR-mediated signaling pathways are involved in regulating epithelial barrier repair and integrity (Lei-Leston, Murphy \& Maloy, 2017).

A number of research studies have reported that Lactobacillus can stimulate immune cells in a specific way that enhances their response functions, as well as acting to maintain a normal immune response, regulate cytokine release (Liu et al., 2011), reduce harmful or excessive inflammation (Ménard et al., 2004), and maintain the intestinal barrier function (Laval et al., 2015). Does Lactobacillus maintain the intestinal barrier function via NLR-mediated signaling pathways? Few studies have investigated this question in weaned piglets. Therefore, we evaluated the effects of a newly isolated $L$. acidophilus strain on the growth performance, intestinal barrier function, and the expression of NLR signaling pathway-related genes in weaned piglets. Our results indicate that dietary supplementation with $L$. acidophilus enhances intestinal barrier functioning by inhibiting IL-1 $\beta$ and IL-18 pro-inflammatory cytokines via the NOD1/NLRP3 signaling pathway in the weaned piglets.

\section{MATERIALS AND METHODS}

The animal care and use protocols were approved by the Review Committee for the Use of Institutional Animal Care and Use Committee of Henan Agricultural University (Protocol no. 20161030). 
109

110

111

112

113

114

115

116

117

118

119

120

121

122

123

124

125

126

127

128

129

\section{Lactobacillus acidophilus strain}

The L. acidophilus strain used in this study was isolated from the excrement of a healthy piglet.

The bacterium was cultured in MRS medium under anaerobic conditions at $37{ }^{\circ} \mathrm{C}$ for $24 \mathrm{~h}$, and the culture medium was centrifuged at $3,000 \times \mathrm{g}$ for $10 \mathrm{~min}$ at $4{ }^{\circ} \mathrm{C}$. The strain was powdered by vacuum freeze drying (Tofflon, Shanghai, China) at a concentration of $5 \times 10^{10}$ colony-forming units (CFU)/g of freeze-dried Lactobacillus powder. The bacterial concentration was measured with an ultraviolet (UV) spectrophotometer (Nano Drop, Thermo Fisher, USA) at a wavelength of $550 \mathrm{~nm}$.

\section{Animals and experimental design}

Sixteen crossbred (Duroc $\times$ Large White $\times$ Landrace) healthy piglets were weaned at 28 days of age. After acclimatization for 3 days, the piglets were stochastically divided on the basis of their initial bodyweights into two groups into eight replicate pens ( $\mathrm{n}=8$ each). (1) In the control group, the piglets were fed a corn-soybean basal diet. (2) In the treatment group, the piglets were fed the same diet supplemented with $0.1 \%$ L. acidophilus (Qiao et al., 2015). The animals were housed individually in metabolic cages $\left(1.0 \times 0.5 \times 0.8 \mathrm{~m}^{3}\right)$ with natural light, and fed four times daily (08:00, 12:00, 16:00, and 20:00) for 14 days, with water provided ad libitum. The room temperature was maintained at $25-28{ }^{\circ} \mathrm{C}$. The basic diet composition and nutrient levels are shown in Table 1.

\section{Sample collection}

At the end of the trial, all piglets were weighed. The final body weight (FBW), average daily feed intake (ADFI), average daily gain (ADG), and feed/gain ratio (F/G) were recorded during 
130

131

132

133

134

135

136

137

138

139

140

141

142

143

144

145

146

147

148

149

150

the trial period. The blood samples were collected from them through the precaval. Then, three

piglets randomly selected from each group were killed by an intracardial injection of sodium

pentobarbital (50 mg/kg bodyweight). The abdominal cavity was opened immediately, and the

jejunum and ileum tissues were collected, washed with phosphate-buffered saline, immediately

frozen in liquid nitrogen, and stored at $-80^{\circ} \mathrm{C}$ for downstream analyses. The jejunum and ileum

were collected at the same site in all the animals. Sera were obtained by centrifuging the blood

samples at $3,000 \times \mathrm{g}$ for $20 \mathrm{~min}$ at $4{ }^{\circ} \mathrm{C}$ followed by storage at $-20^{\circ} \mathrm{C}$ until use.

\section{Serum diamine oxidase (DAO) and D-lactic acid measurements}

Serum DAO was analyzed using a commercial kit (number A088-1; Jiancheng Bioengineering Institute, Nanjing, China) and serum D-lactic acid was analyzed using a commercial enzyme-linked immunosorbent assay kit (number H263; Jiancheng Bioengineering Institute,

Nanjing, China).

\section{Real-time quantitative PCR analyses}

Total RNA was extracted from the jejunum and ileum tissues using TRIzol reagent (Invitrogen, USA), according to the manufacturer's instructions. A UV spectrophotometer (UV754N, Shenzhen, China) was used to determine the RNA concentrations based on their absorbances at $260 \mathrm{~nm}\left(\mathrm{~A}_{260}\right)$. We assessed the purity of the RNA by measuring the $\mathrm{A}_{260} / \mathrm{A}_{280}$ ratio, and the RNA samples typically had $\mathrm{OD}_{260} / \mathrm{OD}_{280}$ ratios of $1.9-2.0$. The integrity of the RNA was analyzed by electrophoresis on a $1 \%$ agarose gel. The PCR templates were reverse transcribed using the All-in-One ${ }^{\mathrm{TM}}$ First-Strand cDNA Synthesis Kit (GeneCopoeia, USA), according to the manufacturer's instructions. Following reverse transcription, real-time quantitative PCR with 
151 SYBR All-in-One ${ }^{\mathrm{TM}}$ qPCR Mix (GeneCopoeia) and the LightCycler- ${ }^{\circ} 96$ Real-Time PCR

152 System (Roche, Switzerland) was used to quantify the expression levels of the occludin, ZO-1,

153 NOD1, receptor interacting serine/threonine kinase 2 (RIPK2), NLR family pyrin domain

154 containing 3 (NLRP3), caspase-1, nuclear factor (NF)- $\mathrm{BB}$, interleukin (IL)-1 $\beta$, IL-18 and $\beta$-actin

155 mRNAs in the jejunum and ileum tissues. The reaction system and program are shown in Table 2

156 and Table 3.

157

The primers were synthesized by the Shanghai Biological Technology Co. (Shanghai, 158 China), and their characteristics are listed in Table 4. The occludin, ZO-1, NOD1, RIPK2, 159 NLRP3, caspase-1, IL-1 $\beta$, and IL-18 primers were designed according to their respective cDNA 160 sequences in GenBank, namely, NM_001163647.2, XM_013993251.1, NM_001114277.1,

XM_021089139.1, NM_001256770.2, NM_214162.1, NM_214055.1, and NM_213997.1. The

primers of NF- $\kappa \mathrm{B}$ and $\beta$-actin cDNA were used as previously described (Chen et al., 2016; Luo

et al., 2017). Three replicates were performed for each reaction and the results were expressed

164 according to their $2^{-\Delta \Delta C T}$ values.

Western blot analysis

166 The tissue samples (50-100 mg) were homogenized in $1 \mathrm{~mL}$ of RIPA Lysis buffer (BOSTER, 167 China) supplemented with protease inhibitors (BOSTER, China) and centrifuged at 12,000 $\times \mathrm{g}$ 168 for $15 \mathrm{~min}$ at $4{ }^{\circ} \mathrm{C}$. Tissue proteins were separated by $10 \%$ sodium dodecyl sulfate169 polyacrylamide gel electrophoresis (SDS-PAGE) and transferred onto the PVDF membranes 170 (biosharp, China). After blocking with $5 \%$ non-fat milk in tris-buffer saline solution buffer 171 (TBST), membranes were incubated with a primary antibodies occludin (Proteintech, China), 
172 173 174 175 176 177 178 179 180

ZO-1 (AVIVA, USA) or $\beta$-actin (Proteintech, China) at $4{ }^{\circ} \mathrm{C}$ overnight and then washed 3 times with TBST for 15 min. Membranes were then incubated with secondary antibodies (Proteintech, China) at room temperature for $1 \mathrm{~h}$. Proteins were visualized using the ECL reagent (BOSTER, China) according to the manufacturer's instructions. Qualification of band intensity was determined with the use of Image $\mathrm{J}$ software and normalized to $\beta$-actin. Antibodies information are shown in Table 5.

\section{Statistical analysis}

The results are expressed as means \pm standard deviations, were analyzed with an independent samples $t$-test, using the SPSS 20.0 software, and statistically significant differences were tested at the 0.05 or 0.01 level.

\section{RESULTS}

\section{Growth performance}

The growth performance results for the piglets are shown in Table 6. There was no significant difference in IBW $(P=0.927)$ and FBW $(P=0.322)$, the treatment group had a lower average initial weight and higher average final weight (neither significant), which meant that the $L$. acidophilus group had a significantly higher weight gain. L. acidophilus supplementation increased the ADG compared with that of the control group $(P=0.015)$. No differences in the ADFI $(P=0.426)$, or $\mathrm{F} / \mathrm{G}(P=0.139)$ were observed between the two dietary treatment groups.

\section{Intestinal physical barrier function}

\section{Serum DAO and D-lactic acid}


193 The results for serum DAO activity and D-lactic acid concentrations of the piglets are shown in

194 Table 7. Dietary supplementation with L. acidophilus was seen to reduce the serum DAO activity $195(P=0.017)$ in the piglets compared with those fed on the control diet. No differences in the 196 serum D-lactic acid concentrations $(P=0.12)$ of the pigs were observed between the two dietary 197 treatment groups.

\section{Relative mRNA expression levels of TJs}

199 The results for relative mRNA expression of TJs genes are presented in Fig 1. L. acidophilus 200 supplementation enhanced the mRNA levels of occludin in the jejunum $(P=0.001)$ and ileum $(P$ $201=0.001)$ tissues of the weaned pigs compared with those in the control group. No differences were observed in the ZO-1 levels in both of these tissues (jejunum: $P=0.138$, ileum: $P=0.43$ ) from the pigs in the two different dietary treatment groups.

\section{Western blot of TJs}

The results for protein expression of occludin and ZO-1 are presented in Fig 2. The diet supplemented with L. acidophilus enhanced the protein levels of occludin in the jejunum $(P<$ $0.001)$ and ileum $(P<0.001)$ tissues of the weaned pigs compared with those in the control group. No differences were observed in the ZO-1 levels in both of these tissues (jejunum: $P=$ 0.087, ileum: $P=0.333$ ) from the pigs in the two different dietary treatment groups.

Relative mRNA expression levels of NLR-signaling pathway-related

\section{genes}

212 The results for relative mRNA expression of NLR-signaling pathway-related genes are presented in Fig 3. Dietary L. acidophilus supplementation greatly reduced the mRNA levels of NOD1 (P 
$214<0.001), \mathrm{NF}-\mathrm{kB}(P=0.001), \mathrm{NLRP} 3(P=0.001)$, caspase-1 $(P=0.003)$ and IL-18 $(P=0.004)$

215 and reduced the mRNA levels of RIPK2 $(P=0.02)$ and IL-1 $\beta(P=0.011)$ in the jejunum tissues

216 of the weaned pigs. Caspase-1 expression was extremely reduced $(P=0.003)$, while that of

217 NLRP3 $(P=0.025)$, IL-1 $\beta(P=0.019)$ and IL-18 $(P=0.015)$ were reduced in the ileum tissues

218 from the weaned pigs. No differences in NOD1 $(P=0.603)$, RIPK2 $(P=0.374)$, NF-kB $(P=$

219 0.184) mRNA levels were observed in the ileum tissues from both of the dietary treatment 220 groups.

DISCUSSION

223 Some weaned piglets have slow growth, a low feed utilization rate, and gastrointestinal

224 physiological disorders such as diarrhea (Lallès et al., 2004). These disorders can be caused by

225 changes in the structure of the gastrointestinal tract or in the intestinal barrier function (Wijtten,

226 van der Meulen \& Verstegen, 2011), compromised immune functioning (Bacou et al., 2017), or

227 other factors. Lactobacillus is the predominant microbe in the intestinal tracts of piglets, where it

228 acts to strengthen the intestinal functions of its hosts (Wu et al., 2016) and inhibit the growth of

229 potentially pathogenic bacteria (Liu et al., 2017). The lactic acid produced by the metabolism of

230 lactic acid bacteria can activate pepsin, degrade carbohydrates, and augment the synthesis of

231 amino acids, thereby improving the digestibility of nutrients and promoting piglet growth. Lan et

232 al. (2017) reported that supplementation with 1, 2, or $3 \mathrm{~g} / \mathrm{kg} \mathrm{L}$. acidophilus increased ADG in

233 weaning pigs during a 14-day trial. Wang et al. (2009) found that the daily gain and feed

234 conversion increased and the occurrence of diarrhea was reduced after the dietary addition of $L$. 
235 fermentum 15007 in piglets. These findings are consistent with our results, but other studies have 236 found that L. acidophilus supplementation had no effect on ADG, ADFI, or F/G in weanling pigs 237 (Zhao \& Kim, 2015). These discrepancies may be attributable to differences in the bacterial 238 strains, pig breeds, dose levels, or feeding environments.

239 Intestinal permeability maintains the organ- and tissue-specific homeostasis required for optimal biological functioning, however, the physiological mechanisms underlying this highly regulated barrier are incompletely understood. Qiao et al. (2015) reported that $0.1 \%$ or $0.2 \% L$. acidophilus supplementation reduced the serum DAO activity in weanling pigs. That our results are consistent with this finding indicates that L. acidophilus is beneficial for the integrity of the intestinal mucosa. TJs control the permeability of the gastrointestinal tract (Tsukita, Furuse \& Itoh, 2001; Turner, 2009), and Lactobacillus has been shown to enhance the expression of TJs (Liu et al., 2014; Yan \& Polk, 2006). Yang et al. (2015) reported that supplementation with L. reuteri $\mathrm{I} 5007$ dramatically enhanced the abundance of the occludin and ZO-1 proteins in the jejunum and ileum tissues of the piglets in their study. Mao et al. (2016) showed that dietary $L$. rhamnosus GG ( $L G G)$ supplementation increased ZO-1, occludin and Bcl-2 mRNA levels and reduced Bax mRNA levels in the jejunum mucosal tissue from weaned pigs, thus indicating that $L G G$ supplementation can improve intestinal permeability by reducing apoptosis. Roselli et al. (2007) reported that L. sobrius supplementation alleviated the membrane damage caused by enterotoxigenic Escherichia coli (ETEC) by suppressing the delocalization of ZO-1 and dephosphorylating occludin. Wang et al. (2016) showed that L. reuteri LR1 prevented the disruption of ZO-1 caused by ETEC, thereby maintaining the barrier integrity of IPEC-1 cell. 
256 The role performed by occludin in TJs remains controversial, and one study reported that

257 intestinal permeability in occludin-knockout mice was not altered, although the mice had 258 unexplained clinical signs such as hyperplasia and chronic inflammation of the gastric epithelium 259 (Balda \& Matter, 2016). The OCEL domain, which mediates occludin interactions, is essential 260 for limiting paracellular macromolecular flux (Buschmann et al., 2013). In the present study, 261 dietary supplementation with L. acidophilus increased the mRNA expression and protein 262 abundance of occludin, but did not affect ZO-1 mRNA expression and protein abundance in the 263 jejunum and ileum. This indicates that L. acidophilus strengthens the TJs of the intestinal mucosa 264 in weaned pigs, but other Lactobacillus strains may differ in their abilities to regulate TJs.

265 Intestinal barrier dysfunction is thought to be involved in the initiation of intestinal inflammation, and NLRs are thought to be involved in maintaining intestinal epithelial function and regulating intestinal inflammation (Sardi et al., 2017). NOD1 responses are potentially involved in both homeostatic and host defense responses to the presence of commensal and pathogenic organisms in the gastrointestinal tract. The immune response triggered by NOD1 is impaired at multiple levels in RIPK2-deficient mice (Magalhaes et al., 2011). Majumdar et al. (2017) showed that W219R and L349P mutants had elevated mRNA expression of the pro-inflammatory cytokines IL-8 and IL-1 $\beta$ after stimulation with the NOD1 ligand, as compared with the wild type NOD1, and these mutations may lead to increased NOD1 signaling and contribute to inflammation in ulcerative colitis. Liu et al. (2017) reported that knocking-down NOD1 substantially inhibited the bacterially induced activation of NF- $\kappa \mathrm{B}$. There is extensive evidence that NOD1 responses to commensal organisms are not only important during the 
277 development of the mucosal immune system in early life (Bouskra et al., 2008), but also later on,

278 in response to infection by important pathogens (Watanabe et al., 2010; Asano et al., 2016).

279 NOD1 overexpression and RNA interference-induced suppression both demonstrate that NOD1

280 is critically involved in the chemokine secretion and NF- $\kappa \mathrm{B}$ activation initiated by $L$.

281 monocytogenes (Opitz et al., 2006). In the present study, L. acidophilus supplementation of the

282 weaned piglets' diets reduced the mRNA expression of NOD1 signaling-related genes in the

283 jejunum, but not in the ileum, which suggests that L. acidophilus activates different NLR

284 signaling pathways in different tissues. The differential expression of NOD1 signaling-related gene expression in distinct intestinal tissues remains an incompletely understood process that requires further study.

A great deal of research has highlighted the vital function of NLRP3 in the intestinal barrier (Mak'Anyengo et al., 2018; Pahwa et al., 2017). Various endogenous and exogenous stimuli activate NLRP3 inflammatory corpuscles through different signaling pathways to activate caspase-1, which promotes the maturation and secretion of the inflammatory cytokines IL-1 $\beta$ and

IL-18 (Miao et al., 2010). Bauer et al. (2010) reported that NLRP3 ${ }^{-/}$mice were markedly protected from dextran sodium sulfate (DSS)-induced colitis, and further studies found that the decline in IL-1 $\beta$ secretion in these mice was dependent on lysosomal maturation and reactive oxygen species. However, it has also been reported that knocking-out caspase-1 led to the loss of epithelial integrity after DSS was administered to the mice (Dupaul-Chicoine et al., 2010). Zaki et al. (2010) reported massive leukocyte infiltration in the colons of NLRP3- or caspase-1-deficient mice. NLRP3-deficient mice were also more susceptible to infection with 
298 Citrobacter rodentium than wild-type mice (Song-Zhao et al., 2014), suggesting that NLRP3

299 expression has a protective effect on the intestinal epithelium. The observed discrepancies in 300 these studies may be attributable to different experimental designs. An attractive hypothesis is 301 that the time-dependent and early activation of NLRP3 induces pyroptosis during the early phase

302

303

304

305

306

307

308

309

310

311

312

313

314

315

316

317 of inflammation (Liu et al., 2013). This hypothesis may explain the protective effect of NLRP3

inhibition on DSS-induced colitis. Recent research has shown that the regulatory network for

NLR signaling is more complex than was initially thought. Our results show that L. acidophilus reduces the expression of IL-1 $\beta$ and IL-18 pro-inflammatory cytokines in weaning piglets, perhaps by inhibiting the NLR signaling pathway. However, the exact mechanism by which $L$. acidophilus regulates NLRs in the intestines of weaned piglets awaits clarification.

\section{Conclusions}

Supplementation with L. acidophilus improved the ADG of weaned piglets, reduced serum DAO activity, increased the mRNA expression and protein abundance of occludin in the jejunum and ileum tissues, inhibited NOD1-signaling-pathway-related genes expression in the jejunum, and inhibited NLRP3-signaling-pathway-related genes expression in the jejunum and ileum tissues.

Therefore, L. acidophilus may enhance the function of the intestinal barrier by down-regulating the expression of IL-1 $\beta$ and IL-18 pro-inflammatory cytokines via the NOD1/NLRP3 signaling pathway in the weaned piglets from this study. 
318

319

320

321

322

323

324

325

326

327

328

329

330

331

332

333

334

335

336

\section{References}

Asano N, Imatani A, Watanabe T, Fushiya J, Kondo Y, Jin X, Ara N, Uno K, Iijima K, Koike T, Strober W, Shimosegawa T. 2016. Cdx2 expression and intestinal metaplasia induced by $H$. pylori infection of gastric cells is regulated by NOD1-mediated innate immune responses. Cancer Research 76:1135-1145 https://doi.org/10.1158/0008-5472.CAN-15-2272.

Balda MS, Matter K. 2016. Tight junctions as regulators of tissue remodeling. Current Opinion in Cell Biology 42:94-101 https://doi.org/10.1016/j.ceb.2016.05.006.

Bacou E, Haurogné K, Mignot G, Allard M, De Beaurepaire L, Marchand J, Terenina E, Billon Y, Jacques J, Bach JM, Mormède P, Hervé J, Lieubeau B. 2017. Acute social stress-induced immunomodulation in pigs high and low responders to ACTH. Physiology \& Behavior 169:1-8 https://doi.org/10.1016/j.physbeh.2016.11.012.

Buschmann MM, Shen L, Rajapakse H, Raleigh DR, Wang Y, Wang Y, Lingaraju A, Zha J, Abbott E, McAuley EM, Breskin LA, Wu L, Anderson K, Turner JR, Weber CR. 2013. Occludin OCEL-domain interactions are required for maintenance and regulation of the tight junction barrier to macromolecular flux. Molecular Biology of the Cell 24:3056-3068 https://doi.org/10.1091/mbc.E12-09-0688.

Bouskra D, Brézillon C, Bérard M, Werts C, Varona R, Boneca IG, Eberl G. 2008. Lymphoid tissue genesis induced by commensals through NOD1 regulates intestinal homeostasis. Nature 456:507-510. https://doi.org/10.1038/nature07450. 
337 Bauer C, Duewell P, Mayer C, Lehr HA, Fitzgerald KA, Dauer M, Tschopp J, Endres S, Latz E,

338

339

340

341

342

343

344

345

346

347

348

349

350

351

352

353

354

355

356

357

Schnurr M. 2010. Colitis induced in mice with dextran sulfate sodium (DSS) is mediated by the NLRP3 inflammasome. Gut 59:1192-1199 https://doi.org/10.1136/gut.2009.197822.

Chen S, Liu Y, Wang X, Wang H, Li S, Shi H, Zhu H, Zhang J, Pi D, Hu CA, Lin X, Odle J. 2016. Asparagine improves intestinal integrity, inhibits TLR4 and NOD signaling, and differently regulates p38 and ERK1/2 signaling in weanling piglets after LPS challenge. Innate Immunity 22:577-587 https://doi.org/10.1177/1753425916664124.

Dupaul-Chicoine J, Yeretssian G, Doiron K, Bergstrom KS, Mclntire CR, LeBlanc PM, Meunier C, Turbide C, Gros P, Beauchemin N, Vallance BA, Saleh M. 2010. Control of intestinal homeostasis, colitis, and colitis-associated colorectal cancer by the inflammatory caspases. Immunity 32:367-378 https://doi.org/10.1016/j.immuni.2010.02.012.

Koch S, Nusrat A. 2009. Dynamic regulation of epithelial cell fate and barrier function by intercellular junction. Annals of the New York Academy of Sciences 1165:220-227 https://doi.org/10.1111/j.1749-6632.2009.04025.x.

Kobayashi K, Inohara N, Hernandez LD, Galán JE, Núñez G, Janeway CA, Medzhitov R, Flavell RA. 2002. RICK/Rip2/CARDIAK mediates signalling for receptors of the innate and adaptive immune systems. Nature 416:194-199 https://doi.org/10.1038/416194a.

Li JY, Lu Y, Hu S, Sun D, Yao YM. 2002. Preventive effect of glutamine on intestinal barrier dysfunction induced by severe trauma. World Journal of Gastroenterology 8:168-171.

Luo X, Guo L, Zhang J, Xu Y, Gu W, Feng L, Wang Y. 2017. Tight Junction Protein Occludin Is a Porcine Epidemic Diarrhea Virus Entry Factor. Journal of Virology 91:e00202-17 
358

359

360

361

362

363

364

365

366

367

368

369

370

371

372

373

374

375

376

377

378

https://doi.org/10.1128/JVI.00202-17.

Li C, Gao M, Zhang W, Chen C, Zhou F, Hu Z, Zeng C. 2016. Zonulin Regulates Intestinal Permeability and Facilitates Enteric Bacteria Permeation in Coronary Artery Disease. Scientific Reports 6:29142 https://doi.org/10.1038/srep29142.

Lei-Leston AC, Murphy AG, Maloy KJ. 2017. Epithelial Cell Inflammasomes in Intestinal Immunity and Inflammation. Frontiers in Immunology 8:1168 https://doi.org/10.3389/fimmu.2017.01168.

Liu Z, Zhang P, Ma Y, Chen H, Zhou Y, Zhang M, Chu Z, Qin H. 2011. Lactobacillus plantarum prevents the development of colitis in IL-10-deficient mouse by reducing the intestinal permeability. Molecular Biology Reports 38:1353-1361 https://doi.org/10.1007/s11033-010-0237-5.

Laval L, Martin R, Natividad JN, Chain F, Miquel S, Desclée de Maredsous C, Capronnier S, Sokol H, Verdu EF, van Hylckama Vlieg JE, Bermúdez-Humarán LG, Smokvina T, Langella P. 2015. Lactobacillus rhamnosus CNCM I-3690 and the commensal bacterium Faecalibacterium prausnitzii A2-165 exhibit similar protective effects to induced barrier hyper-permeability in mice. Gut 6:1-9 https://doi.org/10.4161/19490976.2014.990784.

Lallès JP, Boudry G, Favier C, Le Flo'h N, Luron I, Montagne L, Oswald I, Pié S, Piel C, Sève B. 2004. Gut function and dysfunction in young pigs:physiology. Animal Research 53:301316 https://doi.org/10.1051/animres:2004018.

Liu H, Hou C, Wang G, Jia H, Yu H, Zeng X, Thacker PA, Zhang G, Qiao S. 2017. 
Lactobacillus reuteri I5007 Modulates Intestinal Host Defense Peptide Expression in the Model of IPEC-J2 Cells and Neonatal Piglets. Nutrients 9:559 https://doi.org/10.3390/nu9060559.

Lan R, Koo J, Kim I. 2017. Effects of Lactobacillus acidophilus supplementation on growth performance, nutrient digestibility, fecal microbial and noxious gas emission in weaning pigs. Journal of the Science of Food and Agriculture 97:1310-1315 https://doi.org/10.1002/jsfa.7866.

Liu H, Zhang J, Zhang S, Yang F, Thacker PA, Zhang G, Qiao S, Ma X. 2014. Oral administration of Lactobacillus fermentum I5007 favors intestinal development and alters the intestinal microbiota in formula-fed piglets. Journal of Agricultural and Food Chemistry 62:860-866 https://doi.org/10.1021/jf403288r.

Liu J, Xiang J, Li X, Blankson S, Zhao S, Cai J, Jiang Y, Redmond HP, Wang JH. 2017. NF-кB activation is critical for bacterial lipoprotein tolerance-enhanced bactericidal activity in macrophages during microbial infection. Scientific Reports 7:40418 https://doi.org/10.1038/srep40418.

Liu W, Guo W, Wu J, Luo Q, Tao F, Gu Y, Shen Y, Li J, Tan R, Xu Q, Sun Y. 2013. A novel benzo $[d]$ imidazole derivate prevents the development of dextran sulfate sodium-induced murine experimental colitis via inhibition of NLRP3 inflammasome. Biochemical Pharmacology 85:1504-1512 https://doi.org/10.1016/j.bcp.2013.03.008.

Mariano C, Sasaki H, Brites D, Brito MA. 2011. A look at tricellulin and its role in tight junction formation and maintenance. European Journal of Cell Biology 90:787-796 
400

401

402

403

404

405

406

407

408

409

410

411

412

413

414

415

416

417

418

https://doi.org/10.1016/j.ejcb.2011.06.005.

Ménard S, Candalh C, Bambou JC, Terpend K, Cerf-Bensussan N, Heyman M. 2004. Lactic acid bacteria secrete metabolites retaining anti-inflammatory properties after intestinal transport. Gut 53:821-828.

Mao X, Gu C, Hu H, Tang J, Chen D, Yu B, He J, Yu J, Luo J, Tian G. 2016. Dietary Lactobacillus rhamnosus GG Supplementation Improves the Mucosal Barrier Function in the Intestine of Weaned Piglets Challenged by Porcine Rotavirus. PLoS One 11:e0146312 https://doi.org/10.1371/journal.pone.0146312.

Magalhaes JG, Lee J, Geddes K, Rubino S, Philpott DJ, Girardin SE. 2011. Essential role of Rip2 in the modulation of innate and adaptive immunity triggered by Nod1 and Nod2 ligands. European Journal of Immunology 41:1445-1455 https://doi.org/10.1002/eji.201040827.

Majumdar I, Nagpal I, Paul J. 2017. Homology modeling and in silico prediction of Ulcerative colitis associated polymorphisms of NOD1. Molecular and Cellular Probes 35:8-19 https://doi.org/10.1016/j.mcp.2017.05.009.

Mak'Anyengo R, Duewell P, Reichl C, Hörth C, Lehr HA, Fischer S, Clavel T, Denk G, Hohenester S, Kobold S, Endres S, Schnurr M, Bauer C. 2018. Nlrp3-dependent IL-1 $\beta$ inhibits CD103+ dendritic cell differentiation in the gut. JCI Insight 3:e96322 https://doi.org/10.1172/jci.insight.96322. 
419 Miao EA, Leaf IA, Treuting PM, Mao DP, Dors M, Sarkar A, Warren SE, Wewers MD, Aderem

420 A. 2010. Caspase-1-induced pyroptosis is an innate immune effector mechanism against intracellular bacteria. Nature Immunology 11:1136-1142 https://doi.org/10.1038/ni.1960.

422

423

424

425

426

427

428

429

430

431

432

433

434

435

436

437

438

439

Opitz B, Püschel A, Beermann W, Hocke AC, Förster S, Schmeck B, van Laak V, Chakraborty T, Suttorp N, Hippenstiel S. 2006. Listeria monocytogenes activated p38 MAPK and induced IL-8 secretion in a nucleotide-binding oligomerization domain 1-dependent manner in endothelial cells. The Journal of Immunology 176:484-490.

Peng X, Yan H, You Z, Wang P, Wang S. 2004. Effects of enteral supplementation with glutamine granules on intestinal mucosal barrier function in severe burned patients. Burns 30:135-139 https://doi.org/10.1016/j.burns.2003.09.032.

Pahwa R, Balderas M, Jialal I, Chen X, Luna RA, Devaraj S. 2017. Gut Microbiome and Inflammation: A Study of Diabetic Inflammasome-Knockout Mice. Journal of Diabetes Research 2017:6519785 https://doi.org/10.1155/2017/6519785.

Qiao J, Li H, Wang Z, Wang W. 2015. Effects of Lactobacillus acidophilus dietary supplementation on the performance, intestinal barrier function, rectal microflora and serum immune function in weaned piglets challenged with Escherichia coli lipopolysaccharide. Antonie van Leeuwenhoek 107:883-891 https://doi.org/10.1007/s10482-015-0380-z.

Rodgers LS, Beam MT, Anderson JM, Fanning AS. 2013. Epithelial barrier assembly requires coordinated activity of multiple domains of the tight junction protein ZO-1. Journal of Cell Science 126:1565-1575 https://doi.org/10.1242/jcs.113399.

Roselli M, Finamore A, Britti MS, Konstantinov SR, Smidt H, de Vos WM, Mengheri E. 2007. 
440

441

442

443

444

445

446

447

448

449

450

451

452

453

454

455

456

457

458

459

460

The novel porcine Lactobacillus sobrius strain protects intestinal cells from enterotoxigenic

Escherichia coli K88 infection and prevents membrane barrier damage. The Jounal of

Nutrition 137:2709-2716.

Sperandio B, Fischer N, Sansonetti PJ. 2015. Mucosal physical and chemical innate barriers:

Lessons from microbial evasion strategies. Seminars in Immunology 27:111-118 https://doi.org/10.1016/j.smim.2015.03.011.

Sardi C, Luchini P, Emanuelli A, Giannoni A, Martini E, Manara LM, Sfondrini L, Kallikourdis M, Sommariva M, Rumio C. 2017. Three months of Western diet induces small intestinal mucosa alteration in TLR KO mice. Microscopy Research \& Technique 80:563-569 https://doi.org/10.1002/jemt.22831.

Song-Zhao GX, Srinivasan N, Pott J, Baban D, Frankel G, Maloy KJ. 2014. Nlrp3 activation in the intestinal epithelium protects against a mucosal pathogen. Mucosal Immunology 7:763774 https://doi.org/10.1038/mi.2013.94.

Tanaka H, Takechi M, Kiyonari H, Shioi G, Tamura A, Tsukita, S. 2015. Intestinal deletion of Claudin-7 enhances paracellular organic solute flux and initiates colonic inflammation in mice. Gut 64:1529-1538 https://doi.org/10.1136/gutjnl-2014-308419.

Tsukita S, Furuse M, Itoh M. 2001. Multifunctional strands in tight junctions. Nature Reviews Molecular Cell Biology 2:285-293 https://doi.org/10.1038/35067088.

Turner JR. 2009. Intestinal mucosal barrier function in health and disease. Nature Reviews Immunology 9:799-809 https://doi.org/10.1038/nri2653.

Vella A, Farrugia G. 1998. D-lactic acidosis: pathologic consequence of saprophytism. Mayo 
462

463

464

465

466

467

468

469

470

471

472

473

474

475

476

477

478

479

480

481

Volksdorf T, Heilmann J, Eming SA, Schawjinshi K, Zorn-Kruppa M, Ueck C, Vidal-Y-Sy S, Windhorst S, Jücker M, Moll I, Brandner JM. 2017. Tight Junction Proteins Claudin-1 and Occludin Are Important for Cutaneous Wound Healing. The American Journal of Pathology 187:1301-1312 https://doi.org/10.1016/j.ajpath.2017.02.006.

Wang H, Zhang W, Zuo L, Dong J, Zhu W, Li Y, Gu L, Gong J, Li Q, Li N, Li J. 2014. Intestinal dysbacteriosis contributes to decreased intestinal mucosal barrier function and increased bacterial translocation. Letters in Applied Microbiology 58:384-392 https://doi.org/10.1111/lam.12201.

Wells JM, Rossi O, Meijerink M, van Baarlen P. 2011. Epithelial crosstalk at the microbiotamucosal interface. Proceedings of the National Academy of Sciences of the United States of America 108:4607-4614 https://doi.org/10.1073/pnas.1000092107.

Wijtten PJ, van der Meulen J, Verstegen MW. 2011. Intestinal barrier function and absorption in pigs after weaning: a review. British Journal of Nutrition 105:967-981 https://doi.org/10.1017/S0007114510005660.

Wu Y, Zhu C, Chen Z, Chen Z, Zhang W, Ma X, Wang L, Yang X, Jiang Z. 2016. Protective effects of Lactobacillus plantarum on epithelial barrier disruption caused by enterotoxigenic Escherichia coli in intestinal porcine epithelial cells. Veterinary Immunology and Immunopathology 172:55-63 https://doi.org/10.1016/j.vetimm.2016.03.005.

Wang A, Yu H, Gao X, Li X, Qiao S. 2009. Influence of Lactobacillus fermentum I5007 on the intestinal and systemic immune responses of healthy and E. coli challenged piglets. Antonie 

van Leeuwenhoek 96:89-98 https://doi.org/10.1007/s10482-009-9339-2.

483

484

485

486

487

488

489

490

491

492

493

494

495

496

497

498

499

500

501

502

Wang Z, Wang L, Chen Z, Ma X, Yang X, Zhang J, Jiang Z. 2016. In Vitro Evaluation of Swine-Derived Lactobacillus reuteri: Probiotic Properties and Effects on Intestinal Porcine Epithelial Cells Challenged with Enterotoxigenic Escherichia coli K88. Journal of Microbiology Biotechnology 26:1018-1025 https://doi.org/10.4014/jmb.1510.10089.

Watanabe T, Asano N, Fichtner-Feigl S, Gorelick PL, Tsuji Y, Matsumoto Y, Chiba T, Fuss IJ, Kitani A, Strober W. 2010. NOD1 contributes to mouse host defense against Helicobacter pylori via induction of type I IFN and activation of the ISGF3 signaling pathway. The Journal of Clinical Investigation 120:1645-1662 https://doi.org/10.1172/JCI39481.

Xie L, Chiang ET, Wu X, Kelly GT, Kanteti P, Singleton PA, Camp SM, Zhou T, Dudek SM, Natarajan V, Wang T, Black SM, Garcia JG, Jacobson JR. 2016. Regulation of Thrombin-Induced Lung Endothelial Cell Barrier Disruption by Protein Kinase C Delta. PLoS One 11:e0158865 https://doi.org/10.1371/journal.pone.0158865.

Yan F, Polk DB. 2006. Probiotics as functional food in the treatment of diarrhea. Current Opinion in Clinical Nutrition and Metabolic Care 9:717-721 https://doi.org/10.1097/01.mco.0000247477.02650.51.

Yang F, Wang A, Zeng X, Hou C, Liu H, Qiao S. 2015. Lactobacillus reuteri I5007 modulates tight junction protein expression in IPEC-J2 cells with LPS stimulation and in newborn piglets under normal conditions. BMC Microbiology 15:32 https://doi.org/10.1186/s12866-

$\underline{015-0372-1}$

Zhao PY, Kim IH. 2015. Effect of direct-fed microbial on growth performance, nutrient 
503 digestibility, fecal noxious gas emission, fecal microbial flora and diarrhea score in 504 weanling pigs. Animal Feed Science and Technology 200:86-92 $505 \quad$ https://doi.org/10.1016/j.anifeedsci.2014.12.010.

506 Zaki MH, Boyd KL, Vogel P, Kastan MB, Lamkanfi M, Kanneganti TD. 2010. The NLRP3

507 inflammasome protects against loss of epithelial integrity and mortality during experimental colitis. Immunity 32:379-391 https://doi.org/10.1016/j.immuni.2010.03.003.

509

510

511

512

513

514

515

516

517

518

519

520

521

522

523 
$524 \quad$ Legend

525 Fig 1. The relative mRNA expression of TJs in the intestinal tissues of weaned piglets.

526 Occludin (A) and ZO-1 (B) mRNA relative expression in the jejunum and ileum tissues of

527 weaned piglets. Date represent means $\pm \mathrm{SD}(\mathrm{n}=3$ per group); bars with asterisk(s) $(*$ or $* *)$

528 indicate a statistically significant difference between control and treatment at $P<0.05$ or $P<$

5290.01 (independent-samples $t$-test).

530 Fig 2. The protein abundance of TJs in the intestinal tissues of weaned piglets.

531 The protein abundance of occludin and ZO-1 in the jejunum and ileum tissues of weaned piglets

532 (A). Intensity analysis was performed and normalized to $\beta$-actin (B and C). Date represent means

$533 \pm \mathrm{SD}(\mathrm{n}=3$ per group); bars with $\operatorname{asterisk}(\mathrm{s})(*$ or $* *)$ indicate a statistically significant

534 difference between control and treatment at $P<0.05$ or $P<0.01$ (independent-samples $t$-test).

535 Fig 3. The relative mRNA expression of NLR-signaling-pathway-related genes in the intestinal 536 tissues of weaned piglets.

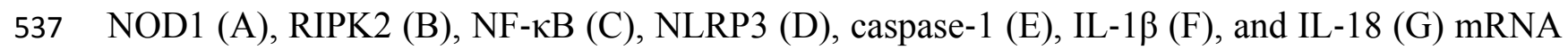
538 relative expression in the jejunum and ileum tissues of weaned piglets. Date represent means \pm $539 \mathrm{SD}(\mathrm{n}=3$ per group); bars with asterisk(s) $(*$ or **) indicate a statistically significant difference 540 between control and treatment at $P<0.05$ or $P<0.01$ (independent-samples $t$-test). 


\section{Supporting information}

546 Raw_data-figure. 1. The relative mRNA expression of TJs in the intestinal tissues of weaned

547 piglets.

548 Raw_data-figure. 2. The protein abundance of TJs in the intestinal tissues of weaned piglets.

549 Raw_data-figure. 3. The relative mRNA expression of NLR-signaling-pathway-related genes in 550 the intestinal tissues of weaned piglets.

Raw- figure. 2.-occludin-jejunum. The protein abundance of occludin in the jejunum tissue of weaned piglets.

Raw- figure. 2.-occludin-ileum. The protein abundance of occludin in the ileum tissue of weaned piglets.

Raw- figure. 2.-ZO-1-jejunum. The protein abundance of ZO-1 in the jejunum tissue of weaned piglets.

Raw- figure. 2.-ZO-1-ileum. The protein abundance of ZO-1 in the ileum tissue of weaned piglets.

Raw- figure. 2.- $\boldsymbol{\beta}$-actin. The protein abundance of $\beta$-actin in the jejunum and ileum tissues of weaned piglets.

Supplemental-file.

Raw data of performance, serum DAO activity, D-lactic acid concentration, the relative mRNA expression and protein abundance of TJs, the relative mRNA expression of NLR-signalingpathway-related genes in the intestinal tissues of weaned piglets. 


\section{Table $\mathbf{1}$ (on next page)}

Composition and nutrient contents of the basal diets (\%w/w, as-fed basis) 
1 Table 1. Composition and nutrient contents of the basal diets ( $\% \mathrm{w} / \mathrm{w}$, as-fed basis)

\begin{tabular}{|c|c|}
\hline Item & Amount \\
\hline \multicolumn{2}{|l|}{ Ingredients, $\%$} \\
\hline Corn & 63.20 \\
\hline Soybean meal, $43 \% \mathrm{CP}$ (crude protein) & 19.00 \\
\hline Whey powder & 4.80 \\
\hline Fish meal, $65 \% \mathrm{CP}$ & 8.60 \\
\hline Glucose & 1.00 \\
\hline Acidifier & 0.30 \\
\hline Calcium hydrogen phosphate & 0.60 \\
\hline Limestone & 0.70 \\
\hline Salt & 0.30 \\
\hline L-Lys $\cdot$ HCL, $78 \%$ Lys & 0.30 \\
\hline DL-Met, 99\% Met & 0.10 \\
\hline $\mathrm{L}^{-\mathrm{Th},}$, 98\% Thr & 0.10 \\
\hline Vitamin and mineral premix ${ }^{\mathrm{a}}$ & 1.00 \\
\hline \multicolumn{2}{|l|}{ Calculated composition } \\
\hline DE (disgestible energy), Mcal $/ \mathrm{kg}$ & 3.25 \\
\hline Lys $(\%)$ & 1.39 \\
\hline Met $(\%)$ & 0.53 \\
\hline \multicolumn{2}{|l|}{ Analyzed composition } \\
\hline Crude protein & 18.65 \\
\hline Calcium & 0.85 \\
\hline Total phosphorus & 0.69 \\
\hline
\end{tabular}

2 a Provided the folloing per kg of diet: Vitamin A, 12,500 IU; Vitamin D, $1250 \mathrm{IU}$; Vitamin E, $125 \mathrm{IU}$; Vitamin B 12 , $90 \mu \mathrm{g}$; Vitamin

$3 \mathrm{~B}_{2}, 10 \mathrm{mg}$; Pantothenic acid, $48 \mathrm{mg}$; Niacin, $35 \mathrm{mg}$; Folic acid, $4.5 \mathrm{mg}$; Biotin, $0.25 \mathrm{mg}$; Fe, $130 \mathrm{mg} ; \mathrm{Zn}, 180 \mathrm{mg} ; \mathrm{Cu}, 15 \mathrm{mg}$; Mn, $430 \mathrm{mg} ; \mathrm{I}, 0.60 \mathrm{mg} ; \mathrm{Se}, 0.25 \mathrm{mg}$. 
Table 2 (on next page)

Amplification reaction system of qPCR 
1 Table 2. Amplification reaction system of qPCR

\begin{tabular}{cc} 
Component & Volume $(\mu \mathrm{L})$ \\
\hline $2 \times$ All-in-One qPCR Mix & $10 \mu \mathrm{L}$ \\
PCR forward primer $(2 \mu \mathrm{M})$ & $2 \mu \mathrm{L}$ \\
PCR reverse primer $(2 \mu \mathrm{M})$ & $2 \mu \mathrm{L}$ \\
Templatec & $2 \mu \mathrm{L}$ \\
RNase Free Water & Up to $20 \mu \mathrm{L}$ \\
\hline
\end{tabular}

2

3

4 


\section{Table $\mathbf{3}$ (on next page)}

\section{Amplification program of qPCR}


Table 3. Amplification program of $\mathrm{qPCR}$

\begin{tabular}{c|ccc}
\hline & Cycle & Temperature & Time \\
\hline preincubation & 1 & $95^{\circ} \mathrm{C}$ & $10 \mathrm{~min}$ \\
\hline \multirow{3}{*}{ Amplification } & 40 & $95^{\circ} \mathrm{C}$ & $10 \mathrm{~s}$ \\
& & $60^{\circ} \mathrm{C}$ & $20 \mathrm{~s}$ \\
& & $72^{\circ} \mathrm{C}$ & $15 \mathrm{~s}$ \\
\hline
\end{tabular}

2 
Table 4 (on next page)

Primer sequences used for the real-time quantitative PCR 
1 Table 4. Primer sequences used for the real-time quantitative PCR

\begin{tabular}{|c|c|c|c|}
\hline Gene & Primer sequences $5^{\prime}-3^{\prime}$ & Product size (bp) & $\mathrm{T}_{\mathrm{m}}\left({ }^{\circ} \mathrm{C}\right)$ \\
\hline Occludin & $\begin{array}{l}\text { F: CAGGTGCACCCTCCAGATTG } \\
\text { R: ATGTCGTTGCTGGGTGCATA }\end{array}$ & 167 & 60 \\
\hline$Z O-1$ & $\begin{array}{l}\text { F: TGCTGGTTTGAAGCCTCCAG } \\
\text { R: GGGGTTTTTGAGGTTCTGGC }\end{array}$ & 134 & 60 \\
\hline NOD1 & $\begin{array}{l}\text { F: ACTGACAGTGGGGTGAAGGT } \\
\text { R: TTTCCCAGTTTCAGGCACTTG }\end{array}$ & 158 & 60 \\
\hline RIPK2 & $\begin{array}{l}\text { F: GTGGATGGGCACAAAATCCAG } \\
\text { R: TGGAAGCACTTTGCAACTTTGT }\end{array}$ & 144 & 60 \\
\hline$N L R P 3$ & $\begin{array}{l}\text { F: TTTGGCTGTTCCTGAGGCAG } \\
\text { R: AGGGCATAGGTCCACACAAA }\end{array}$ & 105 & 60 \\
\hline caspase-1 & $\begin{array}{l}\text { F: CGAACTCTCCACAGGTTCACAA } \\
\text { R: AAGCTTGAGGCTCCСTCTTG }\end{array}$ & 145 & 60 \\
\hline$I L-1 \beta$ & $\begin{array}{l}\text { F: GAAAGCCCAATTCAGGGACC } \\
\text { R: TGCAGCACTTCATCTCTTTGG }\end{array}$ & 172 & 60 \\
\hline$I L-18$ & $\begin{array}{c}\text { F: GTAGCTGAAAACGATGAAGACCTG } \\
\text { R: GGCATATCCTCAAACACGGC }\end{array}$ & 134 & 60 \\
\hline$N F-\kappa B$ & $\begin{array}{l}\text { F: AGTACCCTGAGGCTATAACTCGC } \\
\text { R: TCCGCAATGGAGGAGAAGTC }\end{array}$ & 133 & 60 \\
\hline$\beta$-actin & $\begin{array}{l}\text { F: CTTCCTGGGCATGGAGTCC } \\
\text { R: GGCGCGATGATCTTGATCTTC }\end{array}$ & 201 & 60 \\
\hline
\end{tabular}

2 


\section{Table 5 (on next page)}

Antibodies message 
1 Table 5. Antibodies message

\begin{tabular}{ccccc}
\hline Antibodies & Satalog number & Source & Dilution & Company \\
\hline occludin & 13409-1-AP & Rabbit & $1: 1500$ & Proteintech, China \\
ZO-1 & ARP36636-P050 & Rabbit & $1: 250$ & AVIVA, UAS \\
$\beta$-actin & $60008-1-1 \mathrm{lg}$ & Mouse & $1: 10000$ & Proteintech, China \\
\hline
\end{tabular}

2 
Table 6(on next page)

Effect of dietary treatments on growth performance in weaned piglets 
1 Table 6. Effect of dietary treatments on growth performance in weaned piglets

\begin{tabular}{cccc}
\hline Item & Control & Treatment & $P$ value \\
\hline IBW $(\mathrm{kg})$ & $7.03 \pm 0.48$ & $7.01 \pm 0.30$ & 0.927 \\
FBW (kg) & $10.83 \pm 0.74$ & $11.16 \pm 0.50$ & 0.322 \\
ADFI (g) & $474.88 \pm 61.00$ & $495.27 \pm 35.63$ & 0.426 \\
ADG (g) & $271.97 \pm 20.27^{\mathrm{a}}$ & $296.52 \pm 14.71^{\mathrm{b}}$ & 0.015 \\
F/G & $1.74 \pm 0.10$ & $1.67 \pm 0.08$ & 0.139 \\
\hline
\end{tabular}

2 Each value represents the mean SD of eight replicates, values in the same row with no superscript letter are not significantly

3 different $(P>0.05)$, whereas those with different small superscript letters are significantly different $(P<0.05)$.

4 
Table 7 (on next page)

Effect of dietary treatments on serum DAO activity and D-lactic acid concentration in weaned piglets 
1 Table 7. Effect of dietary treatments on serum DAO activity and D-lactic acid concentration in weaned piglets

\begin{tabular}{|c|c|c|c|}
\hline Item & Control & Treatment & $P$ value \\
\hline $\mathrm{DAO}(\mathrm{U} / \mathrm{ml})$ & $7.40 \pm 0.25^{\mathrm{a}}$ & $7.09 \pm 0.22^{b}$ & 0.017 \\
\hline D-lactic acid (mmol/L) & $2.27 \pm 0.12$ & $2.18 \pm 0.10$ & 0.120 \\
\hline
\end{tabular}

2 Each value represents the mean SD of eight replicates, values in the same row with no superscript letter are not significantly

3 different $(P>0.05)$, whereas those with different small superscript letters are significantly different $(P<0.05)$.

4 


\section{Figure 1 (on next page)}

The relative mRNA expression of TJs in the intestinal tissues of weaned piglets. 

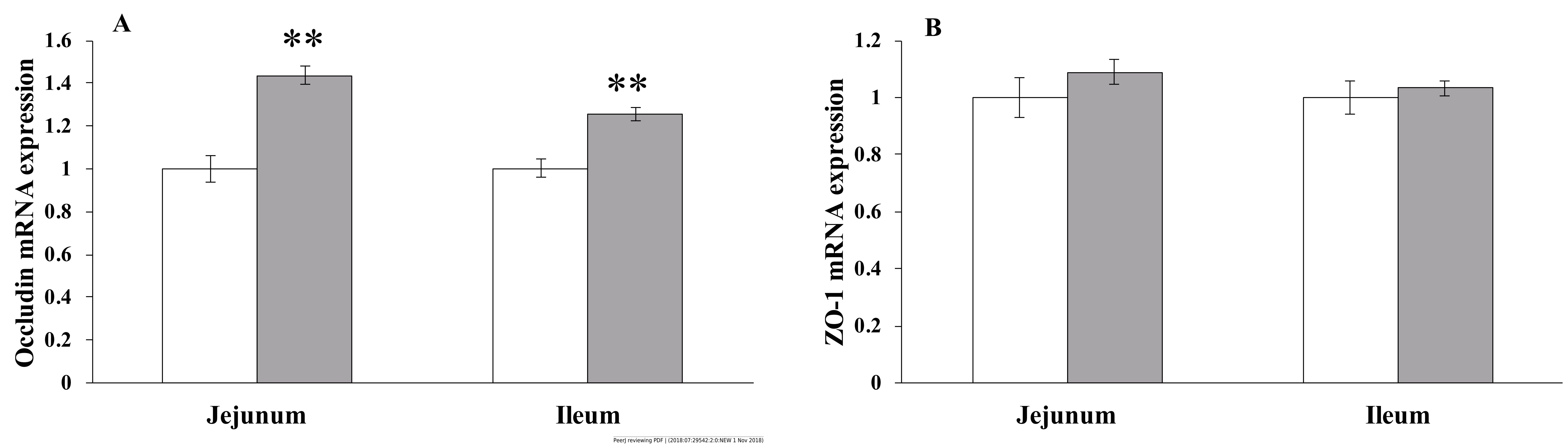
Figure 2 (on next page)

The protein abundance of TJs in the intestinal tissues of weaned piglets. 


\section{A \\ Control Treatment \\ Control Treatment}

occludin

ZO-1

PeerJ

$\beta$-actin

Jejunum

$\square$ Control $\square$ Treatment
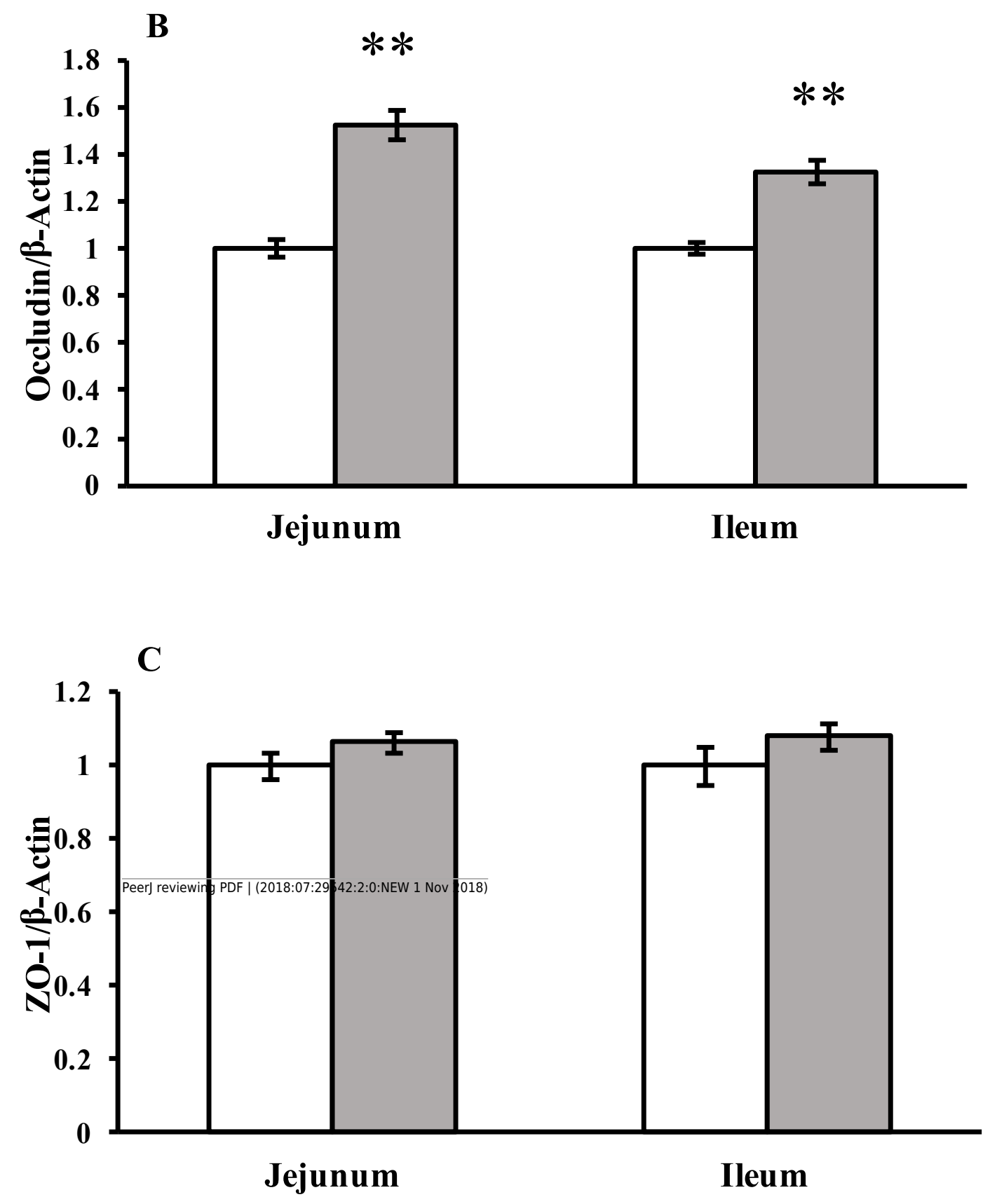


\section{Figure 3 (on next page)}

The relative mRNA expression of NLR-signaling-pathway-related genes in the intestinal tissues of weaned piglets.

NOD1 (A), RIPK2 (B), NF-KB (C), NLRP3 (D), caspase-1 (E), IL-1 $\beta(F)$, and IL-18 (G) mRNA relative expression in the jejunum and ileum tissues of weaned piglets. Date represent means \pm SD ( $\mathrm{n}=3$ per group); bars with asterisk(s) $(*$ or $* *)$ indicate a statistically significant difference between control and treatment at $P<0.05$ or $P<0.01$ (independentsamples $t$-test). 
${ }_{1.2}$ a PeerJ
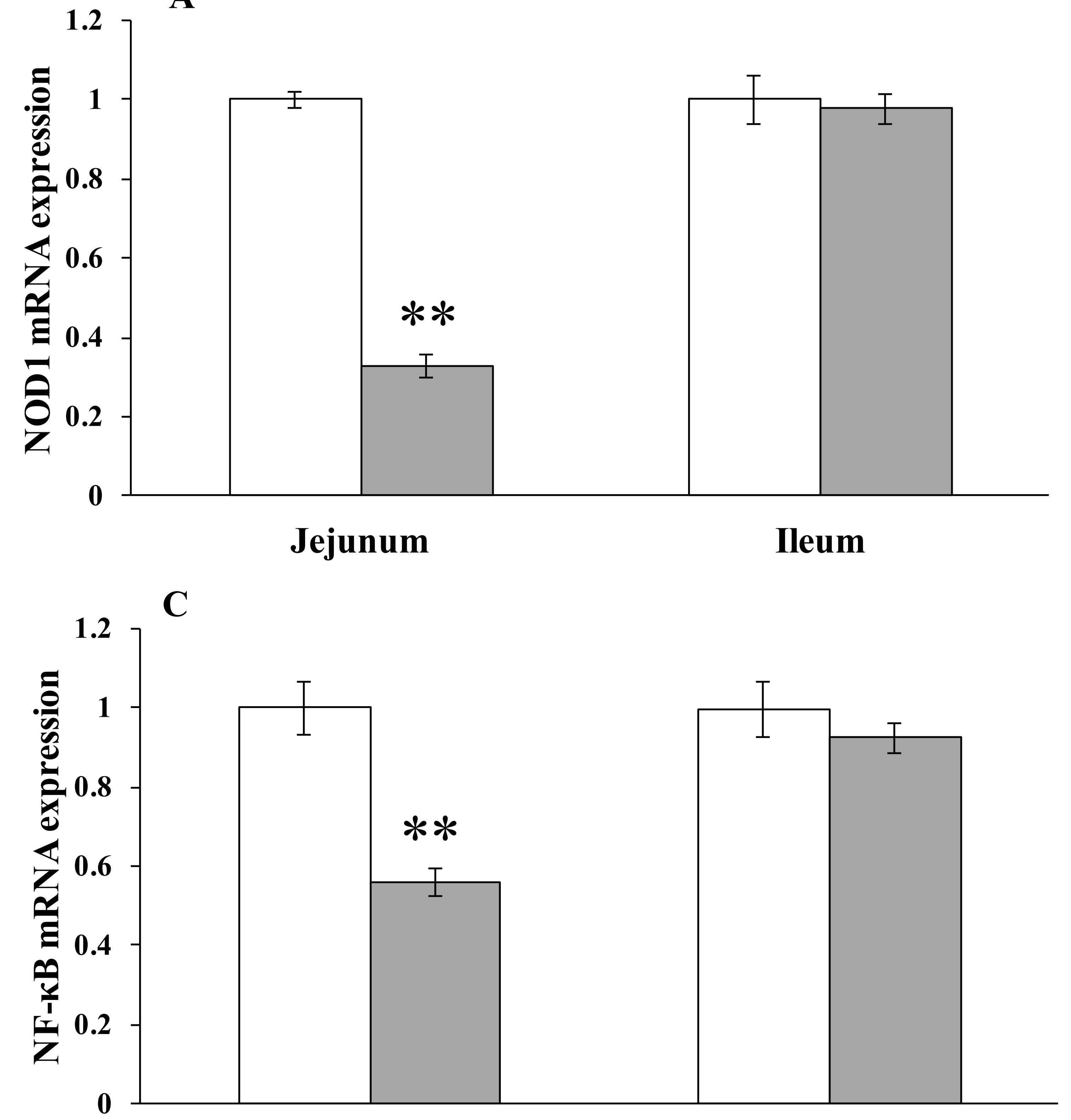

Jejunum
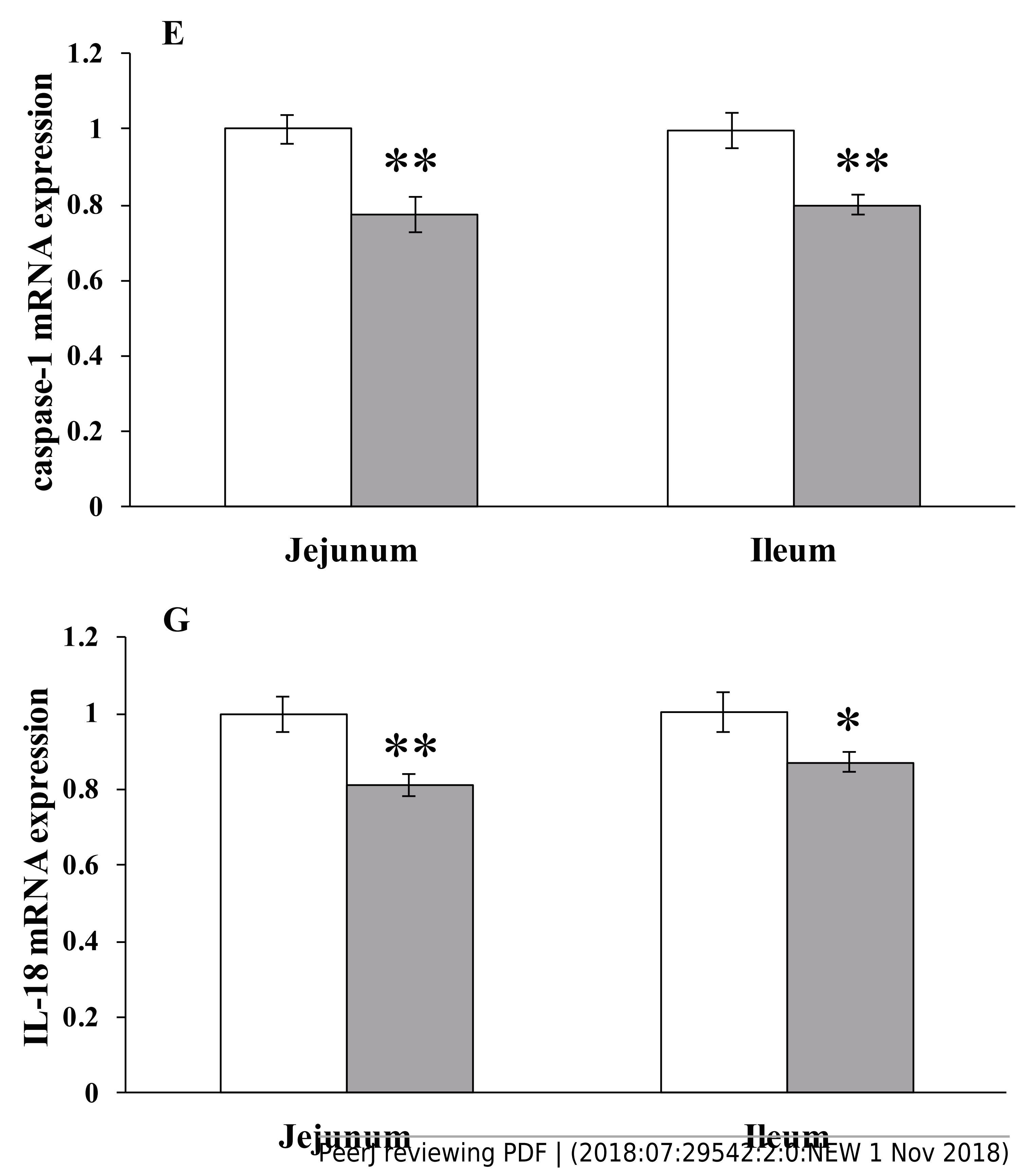

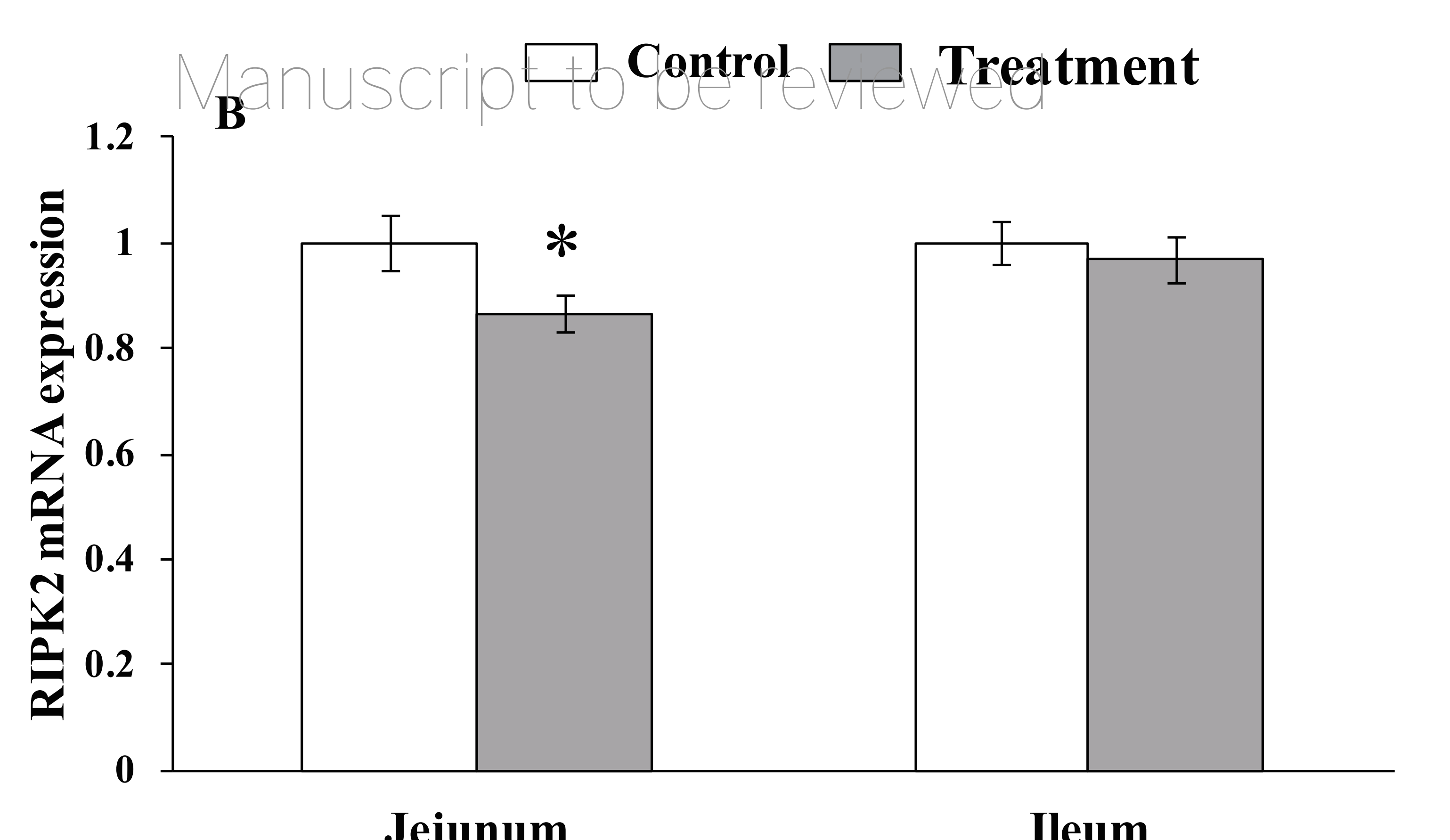

Jejunum
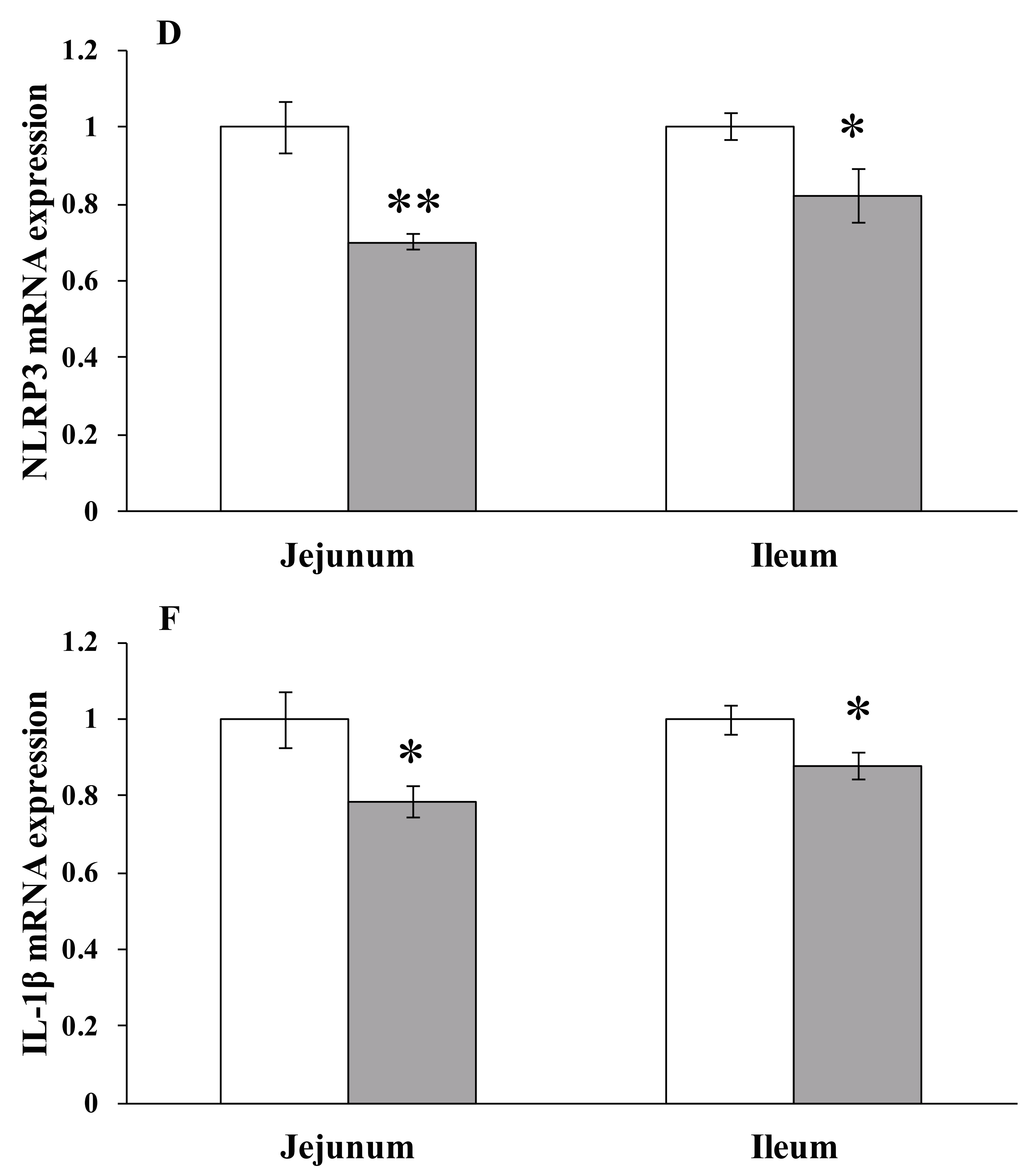